\title{
The Effectiveness of Using Dictionaries as an Aid for Teaching Standardization of English-based Sports Terms in Serbian
}

\author{
Mira Milić, Faculty of Sports and Physical Education, \\ University of Novi Sad, Serbia (mmilic@uns.ac.rs)
}

Tatjana Glušac, Faculty of Law and Business Studies Dr. Lazar Vrkatić, Novi Sad, Union University, Belgrade (tatjana.glusac@gmail.com)

and

Aleksandra Kardoš, doctoral student at Faculty of Philosophy, University of Novi Sad, Serbia (sandra.kardosh@gmail.com)

\begin{abstract}
This paper reports on the effectiveness of a new teaching method employing dictionaries as an aid for teaching the standardization of English-based sports terms in Serbian. The research was conducted among the students of a sports faculty in 2017 by means of a questionnaire distributed to the students both at the beginning of the second half of an ESP course and again at its end. Its aim was to measure the students' progress related to the acquisition of standardized sports terms in Serbian as an indicator of the effectiveness of the new teaching method. The findings generally indicate a certain degree of improvement of the students' knowledge of standardized sports terminology, though a less than satisfactory amount of progress regarding their linguistic competence. Even though the outcomes did not fully meet the goals set in advance, they do provide solid arguments for further efforts in developing and monitoring dictionary use in teaching the standardization of English-based sports terms in Serbian within the ESP curriculum and, even more importantly, for the systematic education of dictionary usage as part of the mother tongue curriculum.
\end{abstract}

Keywords: DICTIONARY USE, ENGLISH, SERBIAN, ESP TEACHING, SPORTS TERMINOLOGY, STANDARDIZATION

Opsomming: Die effektiwiteit van die gebruik van woordeboeke as hulpmiddels in die onderrig van die standaardisering van Engelsgebaseerde sportterme in Serwies. In hierdie artikel word verslag gedoen oor die effektiwiteit van 'n nuwe onderrigmetode waarin woordeboeke benut word as hulpmiddels in die onderrig van die standaardisering van Engelsgebaseerde sportterme in Serwies. Hierdie navorsing is in 2017 uitgevoer onder die studente van 'n sportfakulteit deur middel van ' $n$ vraelys wat aan die begin van die tweede helfte van 'n ESD-kursus en weer aan die einde daarvan aan die studente uitgedeel is. Dit 
het die evaluering van die studente se vordering ten opsigte van die aanleer van gestandaardiseerde sportterme in Serwies ten doel gehad wat 'n aanduiding sou wees van die effektiwiteit van die nuwe onderrigmetode. Die bevindings dui oor die algemeen op 'n mate van verbetering van die studente se kennis van gestandaardiseerde sportterminologie, maar dui ook op minder bevredigende vordering ten opsigte van hul taalkundige vaardigheid. Alhoewel die resultate nie die doelwitte wat aanvanklik gestel is ten volle bevredig het nie, verskaf dit steeds grondige argumente vir verdere pogings in die ontwikkeling en monitering van woordeboekgebruik in die onderrig van die standaardisering van Engelsgebaseerde sportterme in Serwies in die ESD-kurrikulum en, selfs belangriker nog, vir die sistematiese onderrig van woordeboekgebruik as deel van die moedertaalkurrikulum.

Sleutelwoorde: WOORDEBOEKGEBRUIK, ENGELS, SERWIES, ESD-ONDERRIG, SPORTTERMINOLOGIE, STANDAARDISERING

\section{Introduction}

This paper reports on the effectiveness of an innovative course of English for Specific Purposes (henceforward referred to as ESP) focused on dictionary use in teaching the standardization of sports terms in Serbian. The course was taught at the Faculty of Sport and Physical Education in Novi Sad in 2017. Given the fact that the literature (Chun 2004; Lew 2011) confirms that dictionaries are not used in language teaching as much as might be necessary, the course was innovative for three reasons: (1) it required the use of dictionaries for teaching standard English-based sports terms in Serbian as a teaching resource, not as a reference book, (2) it emphasized the teaching of the standardization of sports terms, which is not a common practice in ESP teaching, although it is highly desirable, and (3) it promoted the development of contact linguistic competence, which is stressed in literature as an essential component of an ESP course (Prćić 2014). Special attention is paid to the effectiveness of an English-Serbian Dictionary of Sports Terms (Englesko-srpski rečnik sportskih termina) (Milić 2006), to be referred to henceforward as ESDST, since it is the first bilingual sports dictionary whose Serbian equivalents are subjected to the process of standardization. Building on the first author's previous research into dictionary use in teaching ESP (Milić 2016), it is assumed that such a dictionary can significantly contribute to developing a proper approach towards the increasing influx of lexical and other borrowings from English into Serbian. For this reason, the dictionary should be given the status of one of the compulsory ESP teaching resources for building contact linguistic competence (henceforward referred to as CLC), which is "a type of linguistic knowledge related to the use of elements, i.e., words and names, from English as the nativized foreign language in a non-English language that regularly comes into contact with it" (Prćić 2014: 147). The paper is divided into six sections. Following the introduction, Section 2 outlines the theoretical background, Section 3 deals with research methodology, Section 4 presents the research method, Section 5 elabo- 
rates on the research results, while the last, Section 6, summarizes the conclusions. The paper also contains an Appendix, which is an English translation of the Final questionnaire.

\section{Theoretical framework}

This research belongs to the field of teaching ESP and is focused on building ESP students' English-Serbian CLC. Broadly speaking, the requirement to acquire this special type of knowledge related to contact and contrastive aspects of English and a non-English language has occurred as a result of the current global domination of English (cf. Prćić 2011), which has given rise to an incessant influx of lexical and other borrowings from English into other languages that come into contact with it (cf. Furiassi, Pulcini and Rodríguez González 2012). Under such circumstances, non-English language users are increasingly faced with the need to acquire a new type of linguistic knowledge that has only recently been recognized as CLC (Prćić 2014). According to Prćić (2014: 148-150), building CLC comprises three aspects: practical, theoretical, and pedagogical. The practical aspect focuses on the consistent use of standardized English-based elements in Serbian. The theoretical aspect conflates the achievements of three linguistic disciplines: contact linguistics (in terms of different levels of adaptation of English borrowings in Serbian), contrastive linguistics (regarding the principles of establishing correspondence and equivalence between the particular units of two languages), and sociolinguistics (in terms of the principles of language planning and standardization). Lastly, the pedagogical aspect of building CLC concerns the method of building CLC institutionally, more specifically within the EFL/ESP curriculum. Building on the theoretical aspects of this concept, the exposition in this paper is focused on the practical and pedagogical aspects of this knowledge, which involves predominantly institutionalized forms of language planning, lexicography, and language teaching (Prćić 2014: 152). An overview of the past practical endeavors in this field in non-English languages shows that certain efforts have been made in the field of language planning and lexicography, predominantly in specialized terminology (cf. Laurén and Picht 1993; Myking 1997; Gromann and Schnitzer 2015). In this respect, Antia (2000: XIX) states that "investment in local eco-systems by way of creating and planning terminology in less widely used languages is actually very much in tune with globalization." Keeping in mind the practical aspects of CLC, the following sections deal with CLC-related endeavors in the Serbian linguistic community and the use of dictionaries in the language teaching process.

\subsection{CLC within the framework of English-Serbian language contact}

With respect to the interlingual contacts of English and Serbian, the past few decades have been marked with significant research focused on the linguistic 
standardization of English-based elements in the general lexicon of Serbian. A few studies worth mentioning here are: an exhaustive study of English-based lexical and other borrowings in Serbian (Prćić 2011), the first dictionary of recent Anglicisms (Vasić, Prćić and Nejgebauer 2011; originally 2001), a respelling dictionary of personal names from English (Prćić 2008; originally 1998), and an English-Serbian dictionary of geographical names (Prćić 2004). Narrowing the topic down to specialized terminology in Serbian, the common thread of recent findings is the belief of experts in specialized fields that it is only the English term that can convey the meaning of a term accurately (cf. Prćić 2011: Chapters 11 and 12; Milić 2015a; Silaški 2012). Faced with this overwhelming preference of views regarding the high communicative potential of borrowed English terms, a considerable effort has been devoted to the standardization of specialized registers, the most important examples being related to the fields of computers (Prćić 1996), economics (Silaški 2012), medicine (Mićić and Sinadinović 2013), and sport (Milić 2015a). However, in order to foster knowledge of the standardization requirements related to English-Serbian language contact, the latest research findings suggest the need for building CLC through the educational system, as part of the normal curriculum, which is the practical component of building CLC. To do so it is necessary to employ not only relevant language teaching techniques and resources, but also institutionalized forms of language planning and lexicography. Given that terminological standardization requires not only proposing rules and principles, but also monitoring and updating them (cf. Auger 1986, cited in Cabré 1999: 49; Prćić 2011: 247), it is extremely important to educate members of the language community in standardization issues, as well as to carefully monitor feedback from them and update the set standard with new linguistic and specialized requirements. To establish such two-way communication, it is necessary to put more effort into the compilation of lexicographic resources that could be used not only as reference sources but also as teaching resources, which is the primary subject dealt with in this paper.

\subsection{The use of dictionaries in language teaching}

Even though dictionaries are essential reference books for learning a foreign language, recent research findings indicate that their role in language teaching is often neglected. Empirical interest in the matter, however, has emerged and grown over the past two decades (cf. Lew 2011: 1; Hulstijn and Atkins 1998). Generally, the findings of these studies indicate numerous advantages of dictionary-aided learning (Béjoint 2010; Chi 1998: 575; Hartmann 2001; Hayati and Fattahzadeh 2006; Yamaizumi 2014). One study goes even further, expounding that a dictionary-induced strategy in vocabulary learning is more successful than inferencing from the cognitive science perspective of connectionism (cf. Ellis 2003), since the "rich information of dictionary entries for target words can offer a complexity of connections when multiple aspects of knowledge are con- 
structed" (Zou 2016: 382). However, despite the advantages, the use of dictionaries in language teaching has still not received much attention. According to a number of dictionary-use studies (cf. Chun 2004: 20; Lew 2011), the reason for the lack of interest in the pedagogical function of dictionaries is an insufficient knowledge of lexicographic conventions, which confirms an earlier observation that dictionary users need to be trained in how to use the dictionary in order to solve actual typical problems and questions (cf. Scolfield 1982; Vintean and Matiu 2010: 326; Catelly 2009; Lew 2013; Akbari 2015). Building on this finding, Frankenberg-Garcia (2011) claims that teaching dictionary use should not start with the dictionary itself, but rather with the problems and activities that prompt dictionary consultation. Moreover, dictionary skills comprise a set of defined activities which users need to be able to execute (cf. Lew 2013; Nesi 1999). They should be mastered and honed both within the mother tongue and a foreign language curriculum alike as they not only raise students' awareness of linguistic matters, but also provide them with an abundance of necessary linguistic information and equip them with skills crucial for autonomous learning later in life (Catelly 2009: 501).

Given that good mastery of vocabulary is particularly important for those who learn ESP (cf. Milić 2014: 82; Wu and Wang 2004), a specialized bilingual dictionary is one of the essential means for accomplishing this task in the Anglo-globalized world of today, which is increasingly faced with the requirement of individualization in learning English (cf. Rossner 1985: 98). To this end, Nation (2001) and Nesi (2013) point out that bilingual dictionaries might bring more advantages than monolingual ones, since they offer easily accessible and well thought-out L1-L2 equivalents. With this in mind, two perspectives arise. From the lexicographic perspective, a specialized bilingual dictionary could be used as an ESP teaching resource, which additionally calls for intensive and high quality lexicographic work (Milić 2015b: 184). Viewed from the teaching perspective, this necessitates rethinking and modification of the ESP curriculum, while also monitoring its effects. Employing dictionaries as a teaching resource in ESP courses could lead to desirable learning outcomes. What is more, an attempt should be made to incorporate dictionaries into taskbased activities, since some authors (e.g., Sarani and Sahebi 2012) report that these activities are beneficial in teaching technical vocabulary.

Narrowing the topic of dictionary use in ESP teaching to the specialized register of sport in Serbian, research findings indicate that sports terms in Serbian are currently created most often by the adaptation of English terms through transshaping ${ }^{1}$ and translation (cf. Milić 2015a). In light of the fact that the Internet offers an abundance of information which forces users to adopt information and linguistic expression in a noncritical and selective manner, new sports terms are often insufficiently adapted to the linguistic system of Serbian, which leaves a strong imprint on the L1 standard. A solution to these problems is not only the standardization of English-based sports terms in Serbian, but also training in terminological standardization involving the education of ESP learners as part of the normal curriculum. To this end, the first 
bilingual dictionary of standardized sports terms has been compiled (Milić 2006), and efforts are being made to compile a new English-Serbian dictionary of sports terms in electronic form, as electronic dictionaries are particularly easy to use, being similar to other user-friendly electronic sources and applications (cf. Wang 2012). The model of the standardization of English-based sports terms in Serbian which was applied in the existing dictionary is built on a previous corpus-based study of ball game terms in English and Serbian (Milić 2004), which included six principles arranged in decreasing order of priority: biunivocity, transparency, systematicity, productivity, concision, and frequency. In order to teach students to apply these principles in an appropriate manner, training in standardization was realized by means of lectures and regular taskbased activities focusing on a particular principle of standardized adaptation of borrowed English terms in Serbian. In addition, the students involved in the study were also requested to do three compulsory online tests with multiplechoice answers for the questions posed, which are similar to the questionnaire in the Appendix. The principles are briefly defined and exemplified in the following paragraph ${ }^{2}$.

Bi-univocity is the most important principle, according to which a given term should designate only one concept in a register, e.g., $7 \mathrm{~m}$ line $>$ LINIJA SEDMERCA, but not SEDMERAC, which used to be the same translation equivalent of two English terms, $7 \mathrm{~m}$ line and $7 \mathrm{~m}$ shot. The second most important principle is transparency, which means that the concept a term designates should be inferred without a definition and that it should be motivated etymologically, semantically, or morphologically, e.g., throwing > BACANJE ZA LOPTOM, which is given preference over SUVANJE, as this is archaic. The third principle is systematicity, which means that a term must be in accordance with the linguistic standard of Serbian on the level of: orthography, phonology, and morphosyntax, e.g., playoff > PLEJOF, but not PLAYOFF, since this is a recently borrowed Anglicism in Serbian, which is adapted according to the acoustic impression. The fourth principle is productivity, which means that the standard term should imply a higher derivational and combining potential than its competitors, e.g., held ball > NOŠENA LOPTA, which is given preference over DRUGI KONTAKT S LOPTOM, a term/phrase used previously, since the standard term allows for several derivations of the modifier NOŠEN (NOSITI, NOSILAC, NOŠENJE), whereas the same is not true of the other term. Concision is the fifth principle, which gives preference to a term, justified from the aspect of linguistic economy, e.g., offending player > PREKRŠILAC, which is given preference over IGRAČ KOJI JE NAPRAVIO PREKRŠAJ, which existed before. Finally, the sixth principle of frequency means that the standard term should be the term with the highest frequency of use, e.g., corner kick > KORNER which is given preference over UDARAC SA UGLA, which is used less frequently.

Concerning ESP teaching in the field of sport, practical steps towards the innovation of the ESP curriculum, focused on using dictionaries as an aid in teaching standardization, were taken in 2014, when research was conducted with master students of a sports faculty (cf. Milić 2016). Building on the results 
of that research, the aim of this subsequent research conducted in 2017 with bachelor students of the same faculty was to test the effectiveness of the teaching of ESP using dictionaries as an aid for teaching the standardization of English-based sports terms in Serbian, which is the subject of the following section of this paper. Building on the respective findings, this paper will also attempt to justify the usage of an English-Serbian dictionary of standardized terms not only as a reference book, but also as one of the mandatory ESP teaching resources for building students' CLC.

\section{ESP course design}

The ESP course that served as the grounds for the study generally comprises 60 classes and is taken in the second semester. During the research period, students attended an innovative ESP course focused on the standardization of sports terminology in Serbian and the use of dictionaries, with special emphasis placed on making full use of the English-Serbian dictionary of sports terms ${ }^{3}$ (Milic 2006). To be eligible for the course, all students were expected to have reached a B1 level of English proficiency (Council of Europe 2001), which means that they have mastered a minimum of 2000 general lexical items (cf. Nation 2001: 15).

\subsection{Aims of the innovative ESP course}

In order to train students to be capable of dealing with the challenges encountered in the standardization of English-based sports terms in Serbian, learning is understood as a process-oriented activity in which "the individual develops understanding and awareness and creates possibilities for future learning" (Finney 2002: 73). From this standpoint, special emphasis is placed on good mastery of specialized vocabulary, which is essential for ESP learners (cf. Nation 2001: 187). As Nation (2001) advocates, this can be achieved through ESP exercises by means of exploiting a particular context with certain specialized vocabulary of continuing interest to students while helping learners grasp as much information about each new term as possible by providing them with appropriate activities that ensure multiple encounters with the new terminology, meaning-focused input and output, and fluency development. Moreover, students also need to be instructed on how to reach the standard L1 equivalent in case there is not a direct correspondent in their mother tongue. An inevitable teaching and learning resource in such ESP learning is a dictionary and it is of utmost importance that students learn how to use it for several reasons: (1) it encourages autonomous life-long learning, (2) it is a resource for the acquisition of new vocabulary, (3) it improves students' CLC, (4) it ensures students learn standardized terms, and (5) it contributes to the decrease of the influx of non-standardized English terms that permeate the students' mother tongue. Although dictionary-aided activities can be done in pairs or groups as well, for the aim of this research to be achieved, regular class activities had to be heavily dependent on individualized learning, in which the dictionary plays the role of 
a teaching resource rather than a reference book. Accordingly, it was extremely important to encourage students not only to build the habit of dictionary use but also to learn how to make full use of dictionary information. The number of the respondents who took part in the newly-designed course allowed for this individualized approach, and the authors believed that such an approach would have more productive and long-lasting learning effects. In light of this scenario, this study aimed to assess how well students increased their CLC and to evaluate their progress achieved through the practical application of the dictionary-assisted learning contents related to the standardization of sports terms in Serbian.

\subsection{An innovative ESP course program and its realization}

In order to communicate the general idea of the innovative ESP content in brief, this exposition begins with a flowchart of the course content, shown in Figure 1, which is elaborated upon in more detail in the text that follows.

Using a dictionary in teaching the standardization of English-based sports terms in Serbian necessitated an enquiry into the extent to which students were informed about lexicographic resources and what type of information they looked up in these sources. The enquiry was realized through two administered surveys. The fact that the first half of the course dealt with less specialized texts directed the first survey towards determining the role of general dictionary use for fulfilling communication goals in English. Accordingly, Survey 1 was conducted at the beginning of the ESP course (February 26th). With the aim of gathering background information for the further teaching of standardization, the intention of this survey was to get information on the bilingual and monolingual dictionaries the students used in communicative situations of text reception. In order to get written proof of the information, students were instructed to make a list of reference sources they used. For this task, the students were offered three options: a yes/no question related to whether or not they used dictionaries; if the answer was positive, they were instructed to indicate what information they looked up in one or more dictionaries, as well as to make a list of dictionaries they used, while, if the answer was negative, they were instructed to indicate if they would instead apply a keyword search via the Internet. Even though other options are certainly available, the Internet was the only offered alternative to dictionary use since it had served as the predominant method of lexical disambiguation among previous generations. Building on these findings, an effort was made to prompt dictionary consultation in meaning-focused input/output exercises, which was followed by language-focused instruction (cf. Nation 2002: 267-272). Owing to the fact that ESP texts for reading predominantly deal with specialized topics that ESP students are mostly familiar with, the problem with input exercises is the possibility it enables of unknown words being simply learned rather than fully understood. It was thought that this could potentially be solved by providing suitably- 
graded input in a number of different contexts, which would then be supported by language-focused instruction. Concerning meaning-focused output, it is possible to influence spoken/written production by careful designing and monitoring what vocabulary could be learned from the given tasks. At the end of the first half of the course (April 14th), students attended a lecture on different types of general dictionaries and the quality and quantity of dictionary information, which was followed by a brief introduction to the concept of language standardization and its impact on lexicographic description. Finally, at the very end of the first half of the course, the initial questionnaire was handed out, which will be commented on in more detail in the following section of this paper.

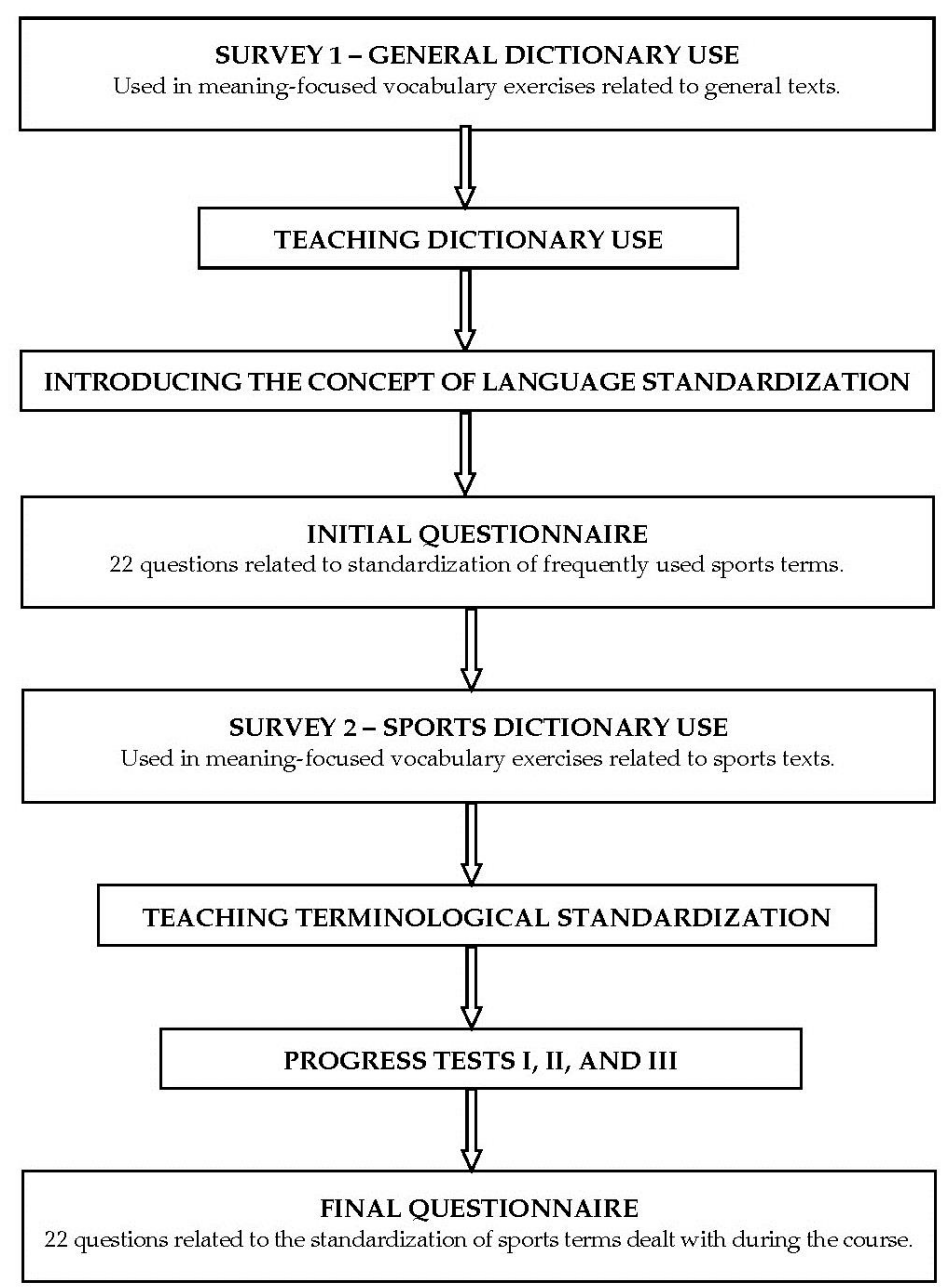

Figure 1: Innovative ESP course design 
Survey 2 was conducted at the beginning of the second half of the course (April 18th), which focused on sports texts. The tasks were the same as in Survey 1, except that in place of general dictionaries, bilingual and monolingual dictionaries of sports terms were prioritized. The major finding of both Survey 1 and Survey 2 is that the general practice of the majority of students was to search the Internet via Keywords rather than consult dictionaries. This probably explains why few students managed to compile a list of more than three dictionaries. While even for those few that did regularly consult a dictionary, they were primarily interested in bilingual sources that provide L1-L2 equivalents, which means that they were likely unaware of what other information a dictionary can offer. This indicates a possible situational negligence towards dictionary use in language teaching and learning, perhaps due to the apparent predominance of the teacher-centered method (cf. Müller 2002: 717-8), as well as to more convenient access to the desired information using various Internet applications.

Following the compiling of the lists of dictionaries and a practical demonstration of how students should use them in meaning-focused input/output exercises, the students attended a lecture on the standardization of Englishbased sports terms in Serbian. This was followed by intermittent in-class discussions of terms of a specific sport from the aspect of standardization, which was complemented by homework assignments related to dictionary consultation aimed at finding information regarding a particular term. During the class, special emphasis was placed on standardization-focused instruction illustrated by examples in the ESDST (Milić 2006). If the dictionary did not provide proper examples, since it includes only terms representative of the five most popular ball games, students were instructed to employ analogies with similar dictionary entries. To motivate students towards higher academic achievement, they were offered an option of compiling an English-Serbian glossary of standardized terms for a sport with which they had dealt, each compilation requiring at least 50 entries, which they were expected to present orally with proper arguments. The main reference source for proposing a standard English-based equivalent in Serbian was the ESDST, which is based on the six principles model of standardization dealt with in Section 2.2. This activity was expected to provide not only an indication of the students' progress in learning, but also give insight into the existing state of sports terminology in Serbian, which is the first stage of standardization.

In order to gain insight into the students' progress in learning the standardization of English-based sports terms in Serbian, three online progress tests were conducted at monthly intervals, which students were expected to solve within a week. Each progress test consisted of 10 English terms with three equivalent terms in Serbian offered as options for each. Students were instructed to choose the one that best fits the Serbian standard, as well as to give an argument for the chosen answer. These tests revealed not only the score of correct answers but also the arguments governing the respondents' answers, 
which provided indirect feedback for developing new teaching activities. Though this component is more relevant for constructing further teaching activities rather than the research itself, the findings can also be taken as an indirect source of information regarding the effectiveness of using dictionaries as an aid for teaching standardization as a main component of building EnglishSerbian CLC. The results of the three tests, which were calculated using IBM SPSS Statistics 20, are presented according to the principles of standardization (Table 1 below).

\begin{tabular}{|c|c|c|c|c|c|c|}
\hline $\begin{array}{c}\text { Progress } \\
\text { test }\end{array}$ & $\begin{array}{c}\text { Bi- } \\
\text { univo- } \\
\text { city }\end{array}$ & $\begin{array}{c}\text { Trans- } \\
\text { parency }\end{array}$ & $\begin{array}{c}\text { System- } \\
\text { aticity }\end{array}$ & $\begin{array}{c}\text { Product- } \\
\text { ivity }\end{array}$ & $\begin{array}{c}\text { Conci- } \\
\text { sion }\end{array}$ & $\begin{array}{c}\text { Fre- } \\
\text { quency }\end{array}$ \\
\hline I & $43.8 \%$ & $65.65 \%$ & $38.55 \%$ & $85.4 \%$ & $81.3 \%$ & $66.7 \%$ \\
\hline II & $27.8 \%$ & $31.67 \%$ & $50.75 \%$ & $28.3 \%$ & $36.9 \%$ & $51.5 \%$ \\
\hline III & $42.37 \%$ & $41.35 \%$ & $59.19 \%$ & $18.4 \%$ & $18.9 \%$ & $41.3 \%$ \\
\hline
\end{tabular}

Table 1: Progress test results related to the principles of standardization

The most important result of the three tests is a decreasing number of correct answers for all the principles of standardization except for systematicity. This could be due to this principle being given special attention in ESP teaching or due to the students not mastering the specialized registers of most sports dealt with during the ESP classes, since the majority of these sports are not taught during the first year of studies. Regarding the arguments behind choosing answers, they appear to be highly diversified. From the highest frequency of use to the lowest, the results were: professional knowledge, lexical/grammatical knowledge, the process of elimination of incorrect answers, the frequency of term use, concision of a term, and knowledge retention from English classes. It is worth mentioning that the students generally demonstrated heavy reliance on professional vocabulary in use, which is probably the reason why they found it difficult to decide whether to borrow or translate terms from English into Serbian. In case of the latter, they showed an excessive reliance on the existing Serbian terms, most of which are stylistically marked units.

In response to this feedback information, further teaching activities were then focused on the adaptation of English-based terms in Serbian with special emphasis placed on the relevant reference sources of information, especially general and specialized dictionaries. Regarding this approach, the authors would also like to emphasize the need to intensify general and specialized lexicographic efforts in Serbian, corresponding additionally to the findings of Prćić $(2016 ; 2018)$ 
and Milic (2015b). Regarding the subjects of this study, a new homework assignment was also introduced which focused on the adaptation of an English term in Serbian that reflected a particular linguistic aspect of terminological standardization. Each word was carefully chosen from the reading text scheduled for a particular class. Students were expected to look up a particular terminological unit in different reference sources in order to find out its meaning, its L1-L2 translation equivalent, relevant grammatical information, and other details, as well as to note down the consulted sources. The answers were discussed at the beginning of the following English class, and the final solution was reached using the ESRST as the main source of reference. As already mentioned, the linguistic competence of students was additionally exercised through the discussion of an English-Serbian glossary of a particular sport that was presented in the form of an oral presentation by advanced students. Despite the students' heavy reliance on professional knowledge rather than the available lexicographic sources, the scores suggest strongly that this activity yielded positive results, since it sensitized students to recognize the potential danger of Anglo-Serbian pseudo-norms.

At the very end of the course (May 31st), the Final questionnaire was administered, and commentary dedicated to it is found in the next section.

\section{Research method}

The research for this study is based on a questionnaire that was conducted in 2017 with 255 first year students of the Faculty of Sport and Physical Education in Novi Sad. In order to examine the effectiveness of the dictionary-aided innovations in teaching ESP, it was necessary to make an assessment of the students' learning practices and to evaluate their progress in the practical application of the dictionary-assisted learning content related to standardization. To do so, two questionnaires were handed out after having obtained the Dean's consent. The Initial questionnaire was conducted on a sample of 167 examinees at the beginning of the second half of the ESP course (April 26th), whereas the Final questionnaire was conducted on a sample of 255 examinees at the end of the course (May 31st). It is worth mentioning here that one potential limitation of the study might be different numbers of examinees, since the Initial questionnaire was administered to 167 students, whereas the number of examinees in the Final questionnaire was 255. Even though the Final questionnaire contained a control question asking whether they had filled the Initial questionnaire or not, which further directed them to proceed with answering only if their answer was positive, it was impossible to match the results of the two research instruments due to the fact that the questionnaire was anonymous, so the cumulative research results for the enrolled students in 2017 are presented. The difference in the number of respondents was probably the result of the Initial questionnaire taking place after the first half of the semester (April 26th), 
when students were not attending classes of English regularly, whereas the Final questionnaire was conducted immediately before the examination term, i.e., on 31st of May, when students were taking a more active role in their studies. In accordance with previous teaching experience of students of sport and the findings of Survey 1 and Survey 2, the students had demonstrated a preference for keyword search via the Internet and therefore this was included as one of the offered answers to each question. Accordingly, both questionnaires consisted of 22 multiple-choice questions related to the standardization of sports terms with predominantly four offered options: standard term, nonstandard term, consult a dictionary, and keyword search via the Internet ${ }^{4}$. The difference between the Initial and Final questionnaire was a difference of exemplification rather than tasks. However, a more important differentiation between the two research instruments concerns the differing interpretation of the last two offered answers in each survey. Namely, consulting a dictionary and keyword search via the Internet in the Initial questionnaire was an indicator of the students' preferred reference source of information, whereas selecting these options in the Final questionnaire indicated the students' failure in terms of the standardization-related learning content. As shown in the Appendix, all standardization principles included several questions, excepting bi-univocity, which was expected to be easily understood since it reflects the requirements of the sports register. The principles are codified as follows: A (bi-univocity), B (transparency), C (systematicity), D (productivity), E (concision), and F (frequency). Accordingly, A examined the students' awareness of the requirement to have a different term for each sports concept (1); B examined the understanding of the meaning of terms in both languages, over-translation, and the use of archaic words in Serbian $(2,3,4,5)$; C included multiple aspects of English-Serbian linguistic standards: collocations, morphosyntax, nominal modifiers, the adaptation of Anglicisms in oblique cases, choosing between Anglicisms and translation equivalents, compounds and semi-compounds, the adaptation of the decimal point in Serbian, and the phonological and morphosyntactic adaptation of Anglicisms (6, 7, 8, 9, 10, 11, 12, 13); D examined the students' ability to apply derivation in order to get a single word-term in Serbian, or to cut down the number of words in a Serbian translation as much as possible $(14,15)$; E examined solving the problem of definitional translation, ${ }^{5}$ in which case it is justified to use an Anglicism or give preference to single-word terms or the fewest words of a phrasal term over multi-word polylexical ones $(16,17,18)$; F tested the students' preference for Anglicisms over translation equivalents (question 19), as well as their understanding of the conditions in which the principle of frequency should (not) be applied $(20,21,22)$.

Correct answers in both questionnaires are shown in Table 2 in percentages initially calculated for each question, and then for a set of questions related to a particular principle of standardization. A comparative analysis of the two questionnaires would be expected to provide information on the students' progress of learning the standardization of sports terms in Serbian, with 
a special emphasis on the process of acquiring CLC, i.e., learning linguistic and English-Serbian contact and contrastive linguistic aspects of terminological standardization in Serbian, which would be expected to be the most demanding task for sports professionals. The findings of this analysis are presented in the following section.

\section{Research results}

The most important finding based on the comparison of the scores of the Initial and Final questionnaire (see Table 2) is a certain extent of improvement related to the six principles of standardization.

\begin{tabular}{|c|c|c|c|c|c|c|}
\hline & \multicolumn{5}{|c|}{ Principles of standardization } \\
\hline $\begin{array}{c}\text { Question- } \\
\text { naire }\end{array}$ & $\begin{array}{c}\text { Bi- } \\
\text { univo- } \\
\text { city }\end{array}$ & $\begin{array}{c}\text { Trans- } \\
\text { parency }\end{array}$ & $\begin{array}{c}\text { System- } \\
\text { aticity }\end{array}$ & $\begin{array}{c}\text { Product- } \\
\text { ivity }\end{array}$ & $\begin{array}{c}\text { Conci- } \\
\text { sion }\end{array}$ & $\begin{array}{c}\text { Fre- } \\
\text { quency }\end{array}$ \\
\hline Initial & $29.94 \%$ & $43.71 \%$ & $32.63 \%$ & $19.76 \%$ & $49.70 \%$ & $33.53 \%$ \\
\hline Final & $51.76 \%$ & $49.90 \%$ & $40.15 \%$ & $77.11 \%$ & $50.46 \%$ & $39.12 \%$ \\
\hline $\begin{array}{c}\text { Improve- } \\
\text { ment }\end{array}$ & $21.82 \%$ & $6.19 \%$ & $7.52 \%$ & $57.35 \%$ & $0.76 \%$ & $5.59 \%$ \\
\hline $\begin{array}{c}\text { Percentage } \\
\text { point } \\
\text { increase }\end{array}$ & \multicolumn{7}{|c|}{$16.53 \%$} \\
\hline
\end{tabular}

Table 2: Comparative indicators of correct answers in the Initial and Final questionnaire

Additionally, the results of the Initial questionnaire are similar to those obtained in 2014 with master students (Milić 2016: 373), since the lowest scores are for bi-univocity $(29.94 \%)$, systematicity $(32.63 \%)$, productivity $(19.76 \%)$, and frequency $(33.53 \%)$. Given that bi-univocity essentially concerns the technical aspect of standardization, the low score is probably due to a substantial disregard for, or inconsistency in the use of, terminological units, whereas systematicity and productivity likely reflect a lack of linguistic knowledge of English and Serbian alike. However, the low score of the frequency principle is contrary to the authors' original expectations, since the exemplified terms are believed to be units with a high frequency of use. The higher score of the trans- 
parency principle, which reflects the technical aspect of standardization, might be explained by the Initial questionnaire's focus only on frequently used sports terms, whereas the high score of the concision principle is probably due to it reflecting the pragmatic aspects of the standardization process, which essentially concerns the use of terms.

Focusing on the progress in learning standardization, the findings of a comparative analysis of the Initial and Final questionnaires indicate improvement in all six principles, amounting to $16.53 \%$ on average. Additionally, the fact that the highest scores in the Final questionnaire were achieved regarding the principles of bi-univocity $(51.76 \%)$ and productivity $(77.11 \%)$ is encouraging, since these principles reflect higher-order linguistic and technical aspects of standardization in the model of Milić $(2006 ; 2015 a)$.

Guided by the findings of the three progress tests, as well as by the results of the previous research with master students, according to which the systematicity principle, which reflects the linguistic aspect of standardization, accounted for the lowest score on the test (cf. Milić 2016: 374), it was considered wise to do the assessment of the students' knowledge of the orthographic and grammatical standard of Serbian. To this end, a certain number of the nonstandard answers provided in the Final questionnaire (see Appendix) were deliberately entered in grammatically and orthographically incorrect forms, as exemplified in question (12a) (the use of a decimal point in Serbian), questions (13b) and (20b) (the use of nonadapted Anglicisms), questions (8a) and (11a), (13a) and (21a) (nonstandard adaptation of noninflectional nominal modifiers in Serbian) and (20a) (the use of English-spelled terms in Serbian). The outcomes of these tasks show an average percentage of incorrect answers of $38.21 \%$ in the Initial questionnaire and $30.03 \%$ in the final one. The lower percentage of incorrect responses in the Final questionnaire suggests a certain level of improvement in terms of linguistic competence in Serbian. However, the analysis of the percentages of incorrect answers according to individual principles reveals a slight increase of $11.54 \%$ for the principle of systematicity in the Final questionnaire, a finding contrary to the authors' original expectations. Though this might be due to the higher number of examinees in the final testing and/or an increase in the amount of grammatically incorrect options in the Final questionnaire, these results suggest a need for rethinking the methods of teaching linguistic issues of standardization in ESP, and perhaps even more so in teaching English as a foreign language at the elementary and pre-intermediate level. Moreover, consideration should also be given to teaching standardization as part of the mother tongue curriculum in order to raise students' linguistic awareness of the rules of standardization.

Another indicator of the students' progress in the practical application of the learning content related to the standardization of sports terms in Serbian is the percentage of answers of dictionary use and/or keyword search via the Internet (see Table 3). 


\begin{tabular}{|l|c|c|}
\hline & Initial questionnaire & Final questionnaire \\
\hline $\begin{array}{l}\text { Looking up a word in a } \\
\text { dictionary }\end{array}$ & $12.92 \%$ & $9.46 \%$ \\
\hline $\begin{array}{l}\text { Keyword search via the } \\
\text { Internet }\end{array}$ & $8.26 \%$ & $5.19 \%$ \\
\hline
\end{tabular}

Table 3: Percentage of answers related to dictionary use and keyword search via the Internet

In light of the fact that the standard term served as one of the offered options in each question, the scores in Table 3 have been interpreted as indicators of the extent to which students had mastered the specialized sports terminology. Accordingly, it can be concluded that the students possessed a fairly advanced knowledge of specialized vocabulary, since the need to consult a dictionary or make a keyword search via the Internet accounts for a rather low percentage in both questionnaires. However, the more significant finding at this stage of research is the slight decrease in the students' preferred activity of searching the keywords via the Internet in favor of dictionary use, which is encouraging given that the Internet is not a reliable source of standard terms in Serbian.

\section{Conclusions}

The study presented in this article is a questionnaire-based investigation into the effectiveness of an innovative curriculum of ESP for undergraduate students of sport, focused on using dictionaries as an aid in teaching the standardization of English-based sports terms in Serbian, as a means of building CLC. To assess the students' learning and evaluate their progress in the practical application of the learning content related to the standardization of sports terms in Serbian, questionnaires were conducted after the second half of the ESP course in 2017 and again at its end (April 26th and May 31st, respectively). The findings indicate an average improvement in student performance of $16.53 \%$ in employing the six principles of standardization applied by Milić (2006), a reduction in grammatically and orthographically incorrect answers, and a slight decrease in students' preference for keyword Internet searching as a direct substitute for dictionary use. All things considered, the results suggest that an ESP course aimed at increasing students' awareness of standardization requirements through the use of user-friendly dictionaries would likely lead to positive learning outcomes. Moreover, the findings indicate the need for further research into the ESP dictionary-aided curriculum, as well as the need to pay more attention to educating dictionary users through the educational system, as part of the normal ESP curriculum and the mother tongue curriculum 
alike. From a wider perspective, there appears to be a need to intensify lexicographic work and include a specialized English-Serbian dictionary in the basic ESP literature as one of the relevant teaching resources for building EnglishSerbian CLC. In order to eliminate the complication of the different numbers of examinees taking the Initial and Final questionnaires, which may have impacted the interpretation of the findings, further research should be even more carefully planned so as to motivate all students towards full cooperation. Perhaps more importantly, the effects of further activities related to dictionary use in teaching the standardization of English-based sports terms in Serbian should be the subject of ongoing monitoring aimed at building English-Serbian CLC among students, through assistance from qualified instructors.

\section{Notes}

1. According to Prćić (2011: 124), "'transshaping' describes the creation of a new form, whose inherent content is taken from English, but which is adapted to the orthographic and semantic standard of Serbian".

2. For more details, see Milić (2015a).

3. A detailed presentation of the macrostructure of the ESRST and its microstructure can be found in Milić (2015a).

4. A translated version of the final questionnaire is presented in the Appendix.

5. According to Prćić (2005: 177-178), definitional translation involves "a translation in the form of concise definition."

\section{Acknowledgements}

A concise version of this paper was presented at the 4th International Conference on English Language and Anglophone Literatures Today (Novi Sad, 25th March 2017). The paper is a part of the research on Project No. 142-451-3684/201701/01, entitled Using Dictionaries in Teaching English for Specific Purposes in Tertiary Education, which is financially supported by the Secretariat for Higher Education and Scientific Research of the Autonomous Province of Vojvodina, Serbia.

The authors are indebted to the reviewers for their invaluable comments, suggestions, and insights.

\section{References}

Akbari, Z. 2015. Key Vocabulary Learning Strategies in ESP and EGP Course Books. International Journal of Applied Linguistics and English Literature 4(1): 1-7. DOI: 10.7575/aiac.ijalel.v.4n.1p.1.

Antia, B.E. 2000. Terminology and Language Planning: An Alternative Framework of Practice and Discourse. Amsterdam/Philadelphia: John Benjamins.

Béjoint, H. 2010. The Lexicography of English: From Origins to Present. Oxford: Oxford University Press. 
Cabré, M.T. 1999. Terminology: Theory, Methods, and Applications. Amsterdam/Philadelphia: John Benjamins. DOI: 10.1075/tlrp.1.

Catelly, Y-M. 2009. Using the WordWeb Online Dictionary in an ESP Class. ANALELE UNIVERSIT ĂtII "DUNĂREA DE JOS" DIN GALAłI FASCICULA XXIV ANUL II 1(2): 501-507.

Chi, M.L.A. 1998. Teaching Dictionary Skills in the Classroom. Fontenelle, T., P. Hiligsmann, A. Michiels, A. Moulin and S. Theissen (Eds.). 1998. Proceedings of the 8th EURALEX International Congress on Lexicography in Liège, Belgium, Part 2: 565-577. Liège: Euralex. Available at: http://euralex.org/publications/teaching-dictionary-skills-in-the-classroom/ [23 January 2017].

Chun, Y.V. 2004. EFL Learners' Use of Print and Online Dictionaries in L1 and L2 Writing Processes. Multimedia-Assisted Language Learning 7(1): 9-35.

Council of Europe. 2001. Common European Framework of Reference for Languages: Learning, Teaching, Assessment. Cambridge: Cambridge University Press.

Ellis, N. 2003. Constructions, Chunking, and Connectionism: The Emergence of Second Language Structure. Doughty, C. and M.H. Long (Eds.). 2003. Handbook of Second Language Acquisition: 33-68. Oxford: Blackwell.

Finney, D. 2002. The ELT Curriculum: A Flexible Model for a Changing World. Richards, J.C. and W.A. Renandya (Eds.). 2002. Methodology in Language Teaching: An Anthology of Current Practice: 69-79. Cambridge: Cambridge University Press.

Frankenberg-Garcia, A. 2011. Beyond L1-L2 Equivalents: Where Do Users of English as a Foreign Language Turn for Help? International Journal of Lexicography 24(1): 97-123. DOI: 10.1093/ijl/ ecq038.

Furiassi, C., V. Pulcini and F. Rodríguez González (Eds.). 2012. The Anglicization of European Lexis. Amsterdam/Philadelphia: John Benjamins Publishing Company.

Gromann, D. and J. Schnitzer. 2015. Where Do Business Students Turn for Help? An Empirical Study on Dictionary Use in Foreign-language Learning. International Journal of Lexicography 29(1): 55-99. DOI: 10.1093/ijl/ecv027.

Hartmann, R.R.K. 2001. Teaching and Researching Lexicography. Harlow: Pearson Education.

Hayati, M. and A. Fattahzadeh. 2006. The Effect of Monolingual and Bilingual Dictionaries on Vocabulary Recall and Retention of EFL Learners. The Reading Matrix 6(2): 125-134.

Hulstijn, J.H. and B.T.S. Atkins. 1998. Empirical Research on Dictionary Use in Foreign-language: Survey and Discussion. Atkins, B.T.S. (Ed.). 1998. Using Dictionaries. Studies of Dictionary Use by Language Learners and Translators. Lexicographica. Series Maior 88: 7-19. Tübingen: Max Niemeyer. Available at: https://pure.uva.nl/ws/files/2239537/165046_Hulstijn_Atkins_1998. pdf [26 November 2016].

Lew, R. 2011. Studies in Dictionary Use: Recent Developments. International Journal of Lexicography 24(1): 1-4. DOI: 10.1093/ijl/ecq044.

Lew, R. 2013. Online Dictionary Skills. Kosem, I., J. Kallas, P. Gantar, S. Krek, M. Langemets and M. Tuulik (Eds.) 2013. Electronic Lexicography in the 21st Century: Thinking Outside the Paper. Proceedings of the eLex 2013 Conference, 17-19 October 2013, Tallinn, Estonia: 16-31. Ljubljana/ Tallinn: Trojina, Institute for Applied Slovene Studies/Eesti Keele Instituut.

Mićić, S. and D. Sinadinović. 2013. Anglicizmi u jeziku medicinske nauke i struke [Anglicisms in the Language of Medical, Scientific and Professional Purposes]. Silaški N. and T. Đurović (Eds.) 2013. Aktuelne teme engleskog jezika i nauke u Srbiji [Contemporary Topics of the English Language and Science in Serbia]: 93-105. Beograd: CID Ekonomskog fakulteta. 
Milić, M. 2004. Termini igara loptom u engleskom jeziku i njihovi prevodni ekvivalenti u srpskom [Ball Game Terms in English and their Translation Equivalents in Serbian]. Unpublished M.A. Thesis. Novi Sad: Faculty of Philosophy, University of Novi Sad.

Milić, M. 2006. Englesko-srpski rečnik sportskih termina [English-Serbian Dictionary of Sports Terms]. Novi Sad: Zmaj.

Milić, M. 2014. Process-oriented Approach to Translating Sports Research Papers from Serbian into English. Eraković, B. and M. Todorova (Eds.). 2014. Topics in Translator and Interpreter Training: Proceedings of the Third Regional Workshop on Translator and Interpreter Training: 71-86. Novi Sad: Faculty of Philosophy.

Milić, M. 2015a. Creating English-based Sports Terms in Serbian: Theoretical and Practical Aspects. Terminology 21(1): 1-22.

Milić, M. 2015b. Principles of Compiling an English-Serbian Dictionary of Sports Terms in the Modern Anglo-globalized World. ESP Today: Journal of English for Specific Purposes at Tertiary Level 3(2): 180-195.

Milić, M. 2016. An English-Serbian Dictionary of Sports Terms as an Aid in Teaching Standardization of English-based Sports Terminology in Serbian. Eraković, B. and M. Todorova (Eds.). 2016. English Studies Today: Prospects and Perspectives. Selected Papers from the Third International Conference English Language and Anglophone Literatures Today (ELALT 3): 369-381. Novi Sad: Filozofski fakultet.

Müller, V. 2002. The Use of Dictionaries as a Pedagogical Resource in the Foreign Language Classroom. Braasch, A. and C. Povlsen (Eds.). 2002. Proceedings of the 10th EURALEX International Congress, EURALEX 2002 Copenhagen, Denmark August 13-17, 2002: 717-721. Copenhagen: Center for Sprogteknologi. Available at: http://www.euralex.org/proceedings-toc/euralex 2002/ [8 January 2015].

Myking, J. 1997. Standardization and Language Planning of Terminology: The Norwegian Experience. International Congress on Terminology, UZEI and HAEE-IVAP, UZEI; HAEE-IVAP: 227-248. Donostia: Gasteiz. Available at: http://www.uzei.com/modulos/usuariosFtp/conexion/ archivos194A.pdf [1 October 2013].

Nation, I.S.P. 2001. Learning Vocabulary in Another Language. Cambridge: Cambridge University Press.

Nation, P. 2002. Best Practice in Vocabulary Teaching and Learning. Richards, J.C. and W.A. Renandya (Eds.). 2002. Methodology in Language Teaching: An Anthology of Current Practice: 267-272. Cambridge: Cambridge University Press.

Nesi, H. 1999. The Specification of Dictionary Reference Skills in Higher Education. Hartmann, R.R.K. (Ed.). 1999. Dictionaries in Language Learning. Recommendations, National Reports, and Thematic Reports from the Thematic Network Project in the Area of Languages, Sub-Project 9: Dictionaries: 53-67. Berlin: Freie Universität Berlin.

Nesi, H. 2013. Dictionary Use by English Language Learners. Language Teaching 47(1): 38-55. DOI: 10.1017/S0261444813000402.

Laurén, C. and H. Picht. 1993. Vergleich der terminologischen Schulen. Laurén, C. and H. Picht (Eds.). 1993. Ausgewühlte Texte zur Terminologie: 493-539. Wien: IITF.

Prćić, T. 1996. Adaptacija i standardizacija kompjuterske terminologije iz engleskog jezika kod nas [Adaptation and Standardization of Computer Terminology from English in Serbian]. Šćepanović, Bogić (Ed.). 1996. Standardizacija terminologije [Standardization of Terminology]: 203-205. Beograd: Srpska akademija nauka i umetnosti. 
Prćić, T. 2004. Englesko-srpski rečnik geografskih imena [An English-Serbian Dictionary of Geographical Names]. Novi Sad: Zmaj.

Prćić, T. 2008. Novi transkripcioni rečnik engleskih ličnih imena. Drugo izdanje [A New Respelling Dictionary of Personal Names from English. Second Edition]. Novi Sad: Zmaj.

Prćić, T. 2011. Engleski u srpskom. 2. izdanje [English within Serbian. Second Edition]. Novi Sad: Filozofski fakultet.

Prćić, T. 2014. Building Contact Linguistic Competence Related to English as the Nativized Foreign Language. System 42: 143-154. DOI: 10.1016/j.system.2013.11.007.

Prćić, T. 2016. Kakav nam opšti rečnik srpskog jezika najviše treba [What Kind of General-purpose Dictionary of Serbian We Need Most]. Ristić, S., Lazić Konjik, I. and N. Ivanović (Eds.) 2016. Leksikologija i leksikografija u svetlu savremenih pristupa: 87-117. Beograd: Institut za srpski jezik SANU.

Prćić, T. 2018. Ka savremenim srpskim rečnicima, Prvo, elektronsko, izdanje [Towards Modern Serbian Dictionaries, The First Digital Edition]. Novi Sad: Faculty of Philosophy. Available at http://digitalna.ff.uns.ac.rs/sadrzaj/2018/978-86-6065-454-2.

Rossner, R. 1985. The Learner as Lexicographer: Using Dictionaries in Second Language Learning. Ilson, R. (Ed.). 1985. Dictionaries, Lexicography and Language Learning: 95-102. Oxford: Pergamon Press/British Council.

Sarani, A. and L.F. Sahebi. 2012. The Impact of Task-based Approach on Vocabulary Learning in ESP Courses. English Language Teaching 5(10): 118-128.

Scolfield, P. 1982. Using the English Dictionary for Comprehension. TESOL Quarterly 16(2): 185194. DOI: $10.2307 / 3586791$.

Silaški, N. 2012. Srpski jezik u tranziciji. O anglicizmima u ekonomskom registru [Serbian in Transition. Anglicisms in the Economic Register]. Beograd: CID Ekonomskog fakulteta.

Vasić, V., T. Prćić and G. Nejgebauer. 2011. Du yu speak anglosrpski? Rečnik novijih anglicizama. 2. izdanje. [Do You Speak Anglo-Serbian? A Dictionary of Recent Anglicisms in Serbian. Second Edition]. Novi Sad: Zmaj.

Vintean, A. and O. Matiu. 2010. Electronic Dictionaries and ESP Students. Studies in Business and Economics 5(3): 324-329.

Wang, J. 2012. The Use of e-Dictionary to Read e-Text by Intermediate and Advanced Learners of Chinese. Computer Assisted Language Learning 25(5): 475-487. DOI: 10.1080/09588221.2011. 631144.

Wu, J. and B. Wang. 2004. The Role of Vocabulary in ESP Teaching and Learning. Oral Presentation at the Fourth International Conference on ELT in China "New Directions in ELT in China", May 21-25, 2004. Available at: http://www.celea.org.cn/pastversion/lw/pdf/wujiangwen.pdf [10 February 2017].

Yamaizumi, M. 2014. Teaching English-Japanese Dictionary Use in University Remedial Courses. Komaba Journal of English Education 5: 1-28.

Zou, D. 2016. Comparing Dictionary-induced Vocabulary Learning and Inferencing in the Context of Reading. Lexikos 26: 372-390. 
Appendix: The Final questionnaire related to the standardization of English-based sports terms in Serbian

To answer, please circle one of the offered solutions.

A

1. If there is only one translation equivalent for two English terms, as exemplified below, what would you do in order to get the standard term in Serbian?

E.g., coach > TRENER versus trainer $>$ KONDICIONI TRENER

(a) Retranslate the English terms as follows: coach > TRENER versus trainer > KONDICIONI TRENER;

(b) Keep the existing translation equivalent (TRENER) for both;

(c) Look it up in a dictionary;

(d) Apply a keyword search via the Internet.

B

2. If there are two translation equivalents for one English term, as exemplified below, what would you do in order to get the standard term in Serbian?

E.g., ball under $>$ POTOPLJENA LOPTA, TOPLJENA LOPTA

(a) Use POTOPLJENA LOPTA;

(b) Use TOPLJENA LOPTA;

(c) Look it up in a dictionary;

(d) Apply a keyword search via the Internet.

3. If an English term is translated to Serbian as exemplified below, what would you do in order to get the standard term in Serbian?

E.g., ear protector $>$ ZAŠTITNIK ZA UŠI, ŠTITNIK ZA UŠI
(a) Use ZAŠTITNIK ZA UŠI;
(b) Use ŠTITNIK ZA UŠI;
(c) Look it up in a dictionary;
(d) Apply a keyword search via the Internet.

4. If an English term has two translation equivalents in Serbian, as exemplified below, what would you do in order to get the standard term in Serbian?

E.g., goalkeeper's border line > GOLMANOVA GRANIČNA LINIJA, GRANIČNA LINIJA ZA GOLMANA
(a) Use GOLMANOVA GRANIČNA LINIJA;
(b) Use GRANIČNA LINIJA ZA GOLMANA;
(c) Look it up in a dictionary;
(d) Apply a keyword search via the Internet. 
5. If an English term has three translation equivalents in Serbian, as exemplified below, what would you do in order to get the standard term in Serbian?

E.g., screw > OKRET, UDARAC IZ OKRETA, ŠRAUBA

(a) Use OKRET;

(b) Use UDARAC IZ OKRETA;

(c) Use ŠRAUBA;

(d) Look it up in a dictionary;

(e) Apply a keyword search via the Internet.

C

6. If an English term is translated to Serbian, as exemplified below, what would you do in order to get the standard term in Serbian?

E.g., sprint won > OSVOJENA LOPTA NA CENTRU, OSVOJENA LOPTA SA CENTRA
(a) Use OSVOJENA LOPTA NA CENTRU;
(b) Use OSVOJENA LOPTA SA CENTRA;
(c) Look it up in a dictionary;
(d) Apply a keyword search via the Internet.

7. If an English term is translated to Serbian, as exemplified below, what would you do in order to get the standard term in Serbian?

E.g., FIFA World Cup > SVETSKI KUP FIFE, FIFA SVETSKI KUP

(a) Use SVETSKI KUP FIFE;

(b) Use FIFA SVETSKI KUP;

(c) Look it up in a dictionary;

(d) Apply a keyword search via the Internet.

8. If an English term comprises a nominal modifier, as exemplified below, what would you do in order to get the standard term in Serbian?

E.g., game point > GEM LOPTA, GEM-LOPTA
(a) Use GEM LOPTA;
(b) Use GEM-LOPTA;
(c) Look it up in a dictionary;
(d) Apply a keyword search via the Internet.

9. If an English term comprises a nominal modifier, as exemplified below, what would you do in order to get the standard term in Serbian?

E.g., final four tournament > TURNIR FAJNALFOR-A, TURNIR FAJNALFORA
(a) Use TURNIR FAJNALFOR-A;
(b) Use TURNIR FAJNALAFORA;
(c) Look it up in a dictionary;
(d) Apply a keyword search via the Internet. 
10. If an English term is adapted using an Anglicism in Serbian, as exemplified below, what would you do in order to get the standard term in Serbian?

E.g., feint > FINTA, VARKA TELOM
(a) Use FINTA;
(b) Use VARKA TELOM;
(c) Look it up in a dictionary;
(d) Apply a keyword search via the Internet.

11. If an English term is adapted using two lexical borrowings, one of which is an Anglicism and the other is a Gallicism, as exemplified below, what would you do in order to get the standard term in Serbian?

E.g., match point > MEČ POEN, MEČ-POEN
(a) Use MEČ POEN;
(b) Use MEČ-POEN;
(c) Look it up in a dictionary;
(d) Apply a keyword search via the Internet.

12. If an English term comprises a decimal point, as exemplified below, what would you do in order to get the standard term in Serbian?

E.g., semicircle $6.25 m>$ POLUKRUG $6.25 \mathrm{M}$, POLUKRUG 6,25 M
(a) Use POLUKRUG $6.25 \mathrm{M}$;
(b) Use POLUKRUG 6,25 M;
(c) Look it up in a dictionary;
(d) Apply a keyword search via the Internet.

13. If an English term cannot be translated to Serbian, as exemplified below, what would you do in order to get the standard term in Serbian?

E.g., kick serve > KIK SERVIS, KICK SERVIS, KIK-SERVIS

D
(a) Use KIK SERVIS;
(b) Use KICK SERVIS;
(c) Use KIK-SERVIS;
(d) Look it up in a dictionary;
(e) Apply a keyword search via the Internet.

14. If an English poly-lexical term has three translation equivalents in Serbian, as exemplified below, what would you do in order to get the standard term in Serbian?

E.g., receiver > PRIMAČ. IGRAČ KOJI PRIMA LOPTU and HVATAČ
(a) Use PRIMAČ;
(b) Use IGRAČ KOJI PRIMA LOPTU; 
(c) Use HVATAČ

(d) Look it up in a dictionary;

(e) Apply a keyword search via the Internet.

15. If an English poly-lexical term has two translation equivalents in Serbian, as exemplified below, what would you do in order to get the standard term in Serbian?

E.g., ineffective side passing > PASIVNO DODAVANJE, DODAVANJE LOPTE OD IGRAČA DO IGRAČA
(a) Use PASIVNO DODAVANJE;
(b) Use DODAVANJE LOPTE OD IGRAČA DO IGRAČA;
(c) Look it up in a dictionary;
(d) Apply a keyword search via the Internet.

$\mathbf{E}$

16. If there are two translation equivalents for one English term, as exemplified below, what would you do in order to get the standard term in Serbian?

E.g., dribbler > DRIBLER, IGRAČ KOJI JE PREVARIO PROTIVNIKA
(a) Use DRIBLER;
(b) Use IGRAČ KOJI JE PREVARIO PROTIVNIKA;
(c) Look it up in a dictionary;
(d) Apply a keyword search via the Internet.

17. If there are two translation equivalents for one English term, as exemplified below, what would you do in order to get the standard term in Serbian?

E.g., sending out > IZBACIVANJE (IGRAČA), DISKVALIFIKACIJA
(a) Use IZBACIVANJE (IGRAČA);
(b) Use DISKVALIFIKACIJA;
(c) Look it up in a dictionary;
(d) Apply a keyword search via the Internet.

18. If there an English term has two translation equivalents in Serbian, as exemplified below, what would you do in order to get the standard term in Serbian?

E.g., external influence > SPOLJNI INCIDENT, INCIDENT VAN IGRE
(a) Use SPOLJNI INCIDENT;
(b) Use SPOLJNI INCIDENT;
(c) Look it up in a dictionary;
(d) Apply a keyword search via the Internet. 
$\mathbf{F}$

19. If an English term is translated as exemplified below, what would you do in order to get the standard term in Serbian?

E.g., ironman triathon $>1$. AJRONMEN, 2. MEGA-TRIJATLON

(a) Use AJRONMEN;

(b) Use MEGA-TRIJATLON;

(c) Look it up in a dictionary;

(d) Apply a keyword search via the Internet.

20. If an English term is adapted using a raw Anglicism in Serbian even though it could have been adapted through translation, as exemplified below, what would you do in order to get the standard term in Serbian?

E.g., flex offence > FLEX OFFENCE, FLEKS-NAPAD
(a) Use FLEX OFFENCE;
(b) Use FLEKS-NAPAD;
(c) Look it up in a dictionary;
(d) Apply a keyword search via the Internet.

21. If an English term is translated in Serbian, as exemplified below, what would you do in order to get the standard term in Serbian?

E.g., straddle support > STREDL IZDRŽAJ, STREDL-IZDRŽAJ
(a) Use STREDL IZDRŽAJ;
(b) Use STREDL-IZDRŽAJ;
(c) Use IZDRŽAJ U PREDNOSU RAZNOŽNO;
(d) Look it up in a dictionary;
(e) Apply a keyword search via the Internet.

22. If an English term has several translation equivalents, as exemplified below, what would you do in order to get the standard term in Serbian?

E.g., center sport > CENTAR, BELA TAČKA, CENTRALNA TAČKA, SREDIŠNJA TAČKA
(a) Use CENTAR;
(b) Use BELA TAČKA;
(c) Use CENTRALNA TAČKA;
(d) Use SREDIŠNJA TAČKA;
(e) Look it up in a dictionary;
(f) Apply a keyword search via the Internet. 